\title{
PREVALENCE OF SUBCLINICAL HYPOTHYROIDISM IN REPRODUCTIVE AGE GROUP WOMEN WITH ABNORMAL UTERINE BLEEDING
}

\author{
Mohana Dhanapal'1, Subha Sivagami Sengodan², Vijaya Subramanian ${ }^{3}$, Hema $^{4}$ \\ ${ }^{1}$ Senior Assistant Professor, Department of Obstetrics \& Gynaecology, Madras Medical College. \\ ${ }^{2}$ Senior Assistant Professor, Department of Obstetrics \& Gynaecology, Madras Medical College. \\ 3 Professor, Department of Obstetrics \& Gynaecology, Madras Medical College. \\ ${ }^{4}$ Post Graduate, Department of Obstetrics \& Gynaecology, Madras Medical College.
}

ABSTRACT
BACKGROUND
In women with menstrual irregularities, thyroid dysfunction has a major share in aetiology and it brings into focus the increased
incidence of hypothyroidism among women with menorrhagia and amenorrhea. The present study by prospective evaluation
method sought to find out the prevalence of subclinical hypothyroidism in reproductive age group women with abnormal uterine
bleeding.

\section{METHODS}

The study population consisted of 250 women attending gynaecology outpatient clinic, Institute of Social Obstetrics and Government Kasturba Gandhi Hospital with the menstrual complaints in the age group of 18-45 years.

\section{RESULTS}

Among 250 women under study majority were in the age group of $25-35$ years (41.2\%); 5.6\% had infertility and $8.8 \%$ had history of abortions.

Majority in the study group had menorrhagia (59.2\%) and oligomenorrhoea (27.2\%). Among 250 women, 20 women (8\%) detected to have a subclinical hypothyroidism.

\section{CONCLUSION}

Our Study Highlights the Following

1. There is a significant association between thyroid disorders and abnormal uterine bleeding.

2. Increased incidence of hypothyroidism among women with menorrhagia and amenorrhea.

3. Early detection by selective screening and specific pharmacotherapy for subclinical thyroid disease early in the course of disease was beneficial.

\section{KEYWORDS}

Subclinical Hypothyroidism, Abnormal Uterine Bleeding, Amenorrhea.

HOW TO CITE THIS ARTICLE: Dhanapal M, Sengodan SS, Subramanian V, et al. Prevalence of subclinical hypothyroidism in reproductive age group women with abnormal uterine bleeding. J. Evolution Med. Dent. Sci. 2016;5(30):1573-1576,

DOI: $10.14260 /$ jemds/2016/370

\section{INTRODUCTION}

Abnormal uterine bleeding is aberrant menstruation characterized by change in cycle length or duration of flow or both. AUB accounts for $10 \%$ of the gynaecology related complaints. Thyroid dysfunction is marked by large number of menstrual aberrations. Both hypothyroidism as well as hyperthyroidism is associated with change in reproductive function including delayed onset of puberty, anovulatory cycles. Menorrhagia is the common manifestation of hypothyroidism. Majority of cases has subclinical hypothyroidism and pass unrecognized and is recognized as risk factor for menstrual problems, cardiovascular diseases and abnormal mental development in foetus.

Hence, this study is to evaluate thyroid function in patients having abnormal menstrual bleeding in reproductive

Financial or Other, Competing Interest: None.

Submission 20-02-2016, Peer Review 18-03-2016,

Acceptance 23-03-2016, Published 14-04-2016.

Corresponding Author:

Dr. Mohana Dhanapal,

40/44, Vanniampathi Street,

Raja Annamalai Puram,

Chennai-600028, Tamilnadu.

E-mail: doctormohana@gmail.com

DOI: $10.14260 /$ jemds $/ 2016 / 370$ age group, which will be justifiable and will help in further management of AUB.

\section{Subclinical Hypothyroidism}

Subclinical hypothyroidism is the term used to define a state in which serum T3 and T4 levels are within normal limits, but there is an underlying mild thyroid failure as evidenced by mild increase in serum TSH. Chronic autoimmune thyroiditis is the leading cause. The other causes are thyroid ablation with radioactive iodine, anti-thyroid drugs, drugs such as amiodarone and lithium. Subclinical hypothyroidism represents the early stage of the disease and it has been shown that there is progression to overt hypothyroidism in $4 \%-18 \%$ of patients who have subclinical hypothyroidism every year.

\begin{tabular}{|c|c|c|c|}
\hline FREE T3 & $\begin{array}{c}\text { FREE } \\
\text { T4 }\end{array}$ & TSH & DIAGNOSIS \\
\hline Normal & Normal & Normal & Euthyroid \\
\hline Elevated & Elevated & Low & Hyperthyroidism \\
\hline Low & Low & Elevated & Hypothyroidism \\
\hline Normal & Normal & Elevated & $\begin{array}{c}\text { Subclinical } \\
\text { Hypothyroidism }\end{array}$ \\
\hline Normal & Normal & Low & $\begin{array}{c}\text { Subclinical } \\
\text { Hyperthyroidism }\end{array}$ \\
\hline \multicolumn{3}{|c|}{ Laboratory Evaluation } \\
\hline
\end{tabular}




\section{AIMS AND OBJECTIVES}

This Study Aimed Analysing the Cross Sectional Population.

- To determine the association between menstrual irregularities and thyroid function.

- To estimate the prevalence of subclinical thyroid disease among reproductive age group women with abnormal uterine bleeding.

\section{MATERIALS AND METHODS}

Study Design: Prospective Analytical Study.

Study Period: August 2008 to September 2009.

\section{Sample Population}

This study population consisted of 250 women attending gynaecology outpatient clinic in Institute of Social Obstetrics and Government Kasturba Gandhi Hospital with the following complaints,

1. Oligomenorrhoea.

2. Hypomenorrhoea.

3. Menorrhagia.

4. Polymenorrhea.

5. Amenorrhea.

\section{Inclusion Criteria}

- Age Group 18-45 years.

- With Menstrual Disturbances.

- No Demonstrable Pelvic Pathology.

- Not an IUCD User.

- Not on Thyroxine Replacement Therapy.

- With Symptoms of Thyroid Dysfunction.

\section{Exclusion Criteria}

- Presence of Palpable Pelvic Pathology.

- Known Thyroid Disorders.

- On Drugs like Aspirin, Heparin, Steroids, Amiodarone, Lithium.

After proper selection of patients, detailed menstrual history and history as to the presence of symptoms of hypothyroidism and hyperthyroidism was taken.

- Evaluation of General Condition of Patient.

- Cardiovascular, Respiratory, Nervous Systems were Evaluated.

- Gentle Abdominal, Speculum and Per Vaginal Examination Done.

- $5 \mathrm{~mL}$ of Venous Blood was taken in a Plain Glass Tube without any Anticoagulant. Morning sample in a fasting state taken and serum was separated to estimate FT3, FT4 and TSH.

\begin{tabular}{|c|c|}
\hline HORMONE & REFERENCE RANGE \\
\hline TSH & $0.5-5.0 \mathrm{mIU} / \mathrm{L}$ \\
\hline FREE T3 & $1.7-4.2 \mathrm{pg} / \mathrm{mL}$ \\
\hline FREE T4 & $0.30-5.5 \mathrm{micro} / \mathrm{IU} / \mathrm{mL}$ \\
\hline \multicolumn{2}{|c|}{ Thyroid Reference Value } \\
\hline
\end{tabular}

\section{RESULTS AND ANALYSIS}

\begin{tabular}{|c|c|c|}
\hline Age Group & Frequency & Percentage \\
\hline 18-24 years & 36 & $14.4 \%$ \\
\hline 25-31 years & 103 & $41.2 \%$ \\
\hline 32-39 years & 81 & $32.4 \%$ \\
\hline >40 years & 30 & $12 \%$ \\
\hline \multicolumn{2}{|c|}{ Table 1: Age Distribution in Study Group } \\
\hline
\end{tabular}

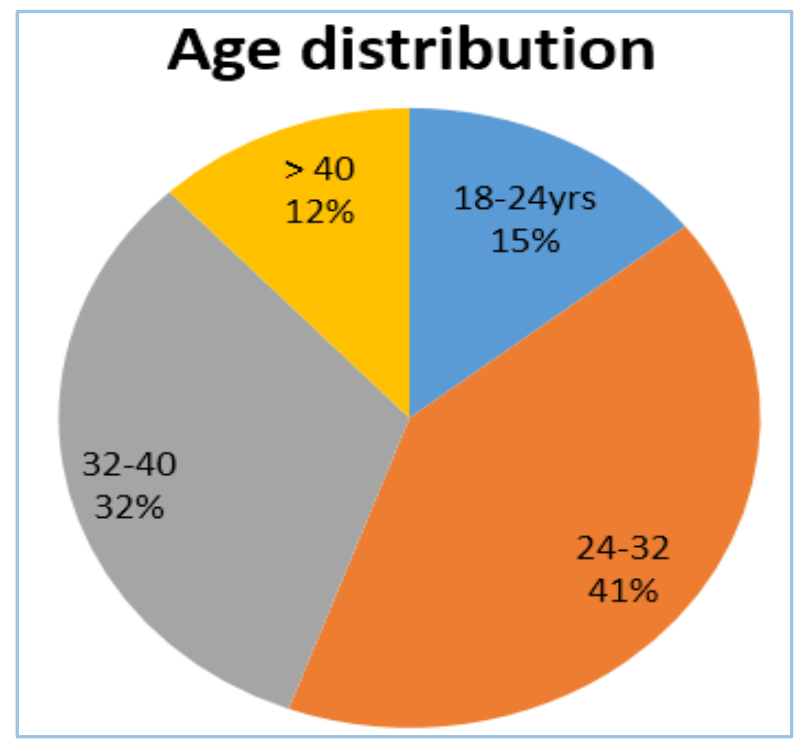

\begin{tabular}{|c|c|c|}
\hline Parity & Frequency & Percentage \\
\hline Nullipara & 27 & $10.8 \%$ \\
\hline P1L1 & 62 & $24.2 \%$ \\
\hline P2L2 & 98 & $39 \%$ \\
\hline Multipara & 63 & $25 \%$ \\
\hline \multicolumn{3}{|c|}{$\begin{array}{l}\text { Table 2: Distribution of } \\
\text { Cases According to Parity }\end{array}$} \\
\hline
\end{tabular}

\section{Parity distribution}

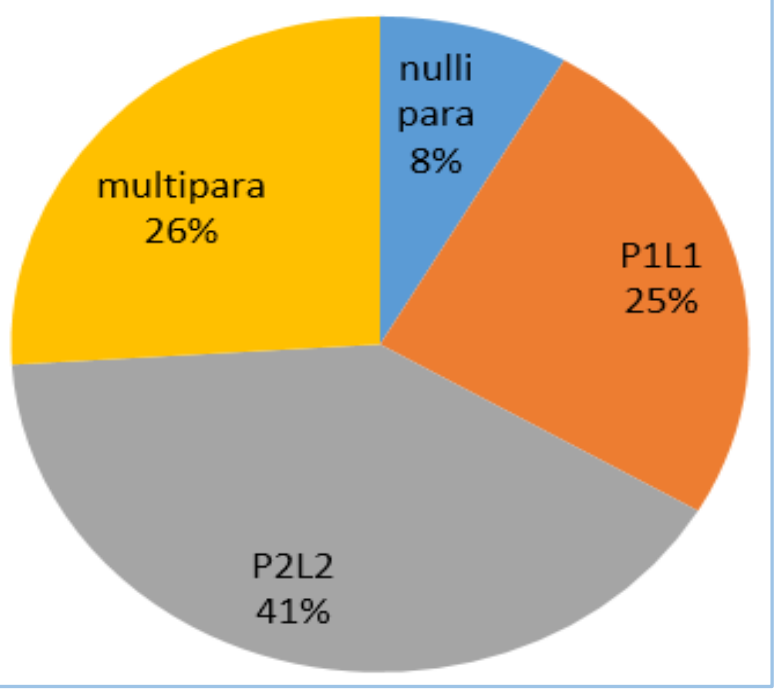

\begin{tabular}{|c|c|c|}
\hline $\begin{array}{c}\text { Reproductive } \\
\text { Dysfunction }\end{array}$ & Number & Percentage \\
\hline Nil & 214 & $85.6 \%$ \\
\hline Infertility & 14 & $5.6 \%$ \\
\hline Pregnancy Wastage & 22 & $8.8 \%$ \\
\hline \multicolumn{2}{|c|}{ Table 3: Reproductive Dysfunction } \\
in Study Group \\
\hline
\end{tabular}




\section{Reproductive dysfunction}

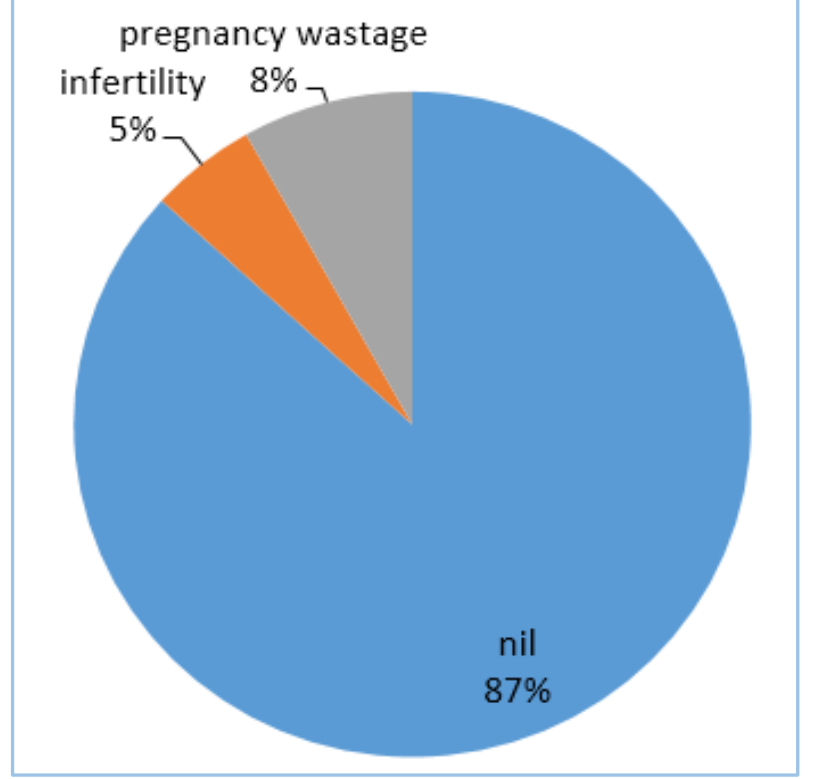

\begin{tabular}{|c|c|c|}
\hline Type & Frequency & Percentage \\
\hline Amenorrhea & 25 & $10 \%$ \\
\hline Menorrhagia & 148 & $59.2 \%$ \\
\hline Oligomenorrhoea & 68 & $27.2 \%$ \\
\hline Hypomenorrhoea & 4 & $1.6 \%$ \\
\hline Polymenorrhea & 5 & $2 \%$ \\
\hline \multicolumn{2}{|c|}{ Table 4: Type of AUB } \\
\hline
\end{tabular}

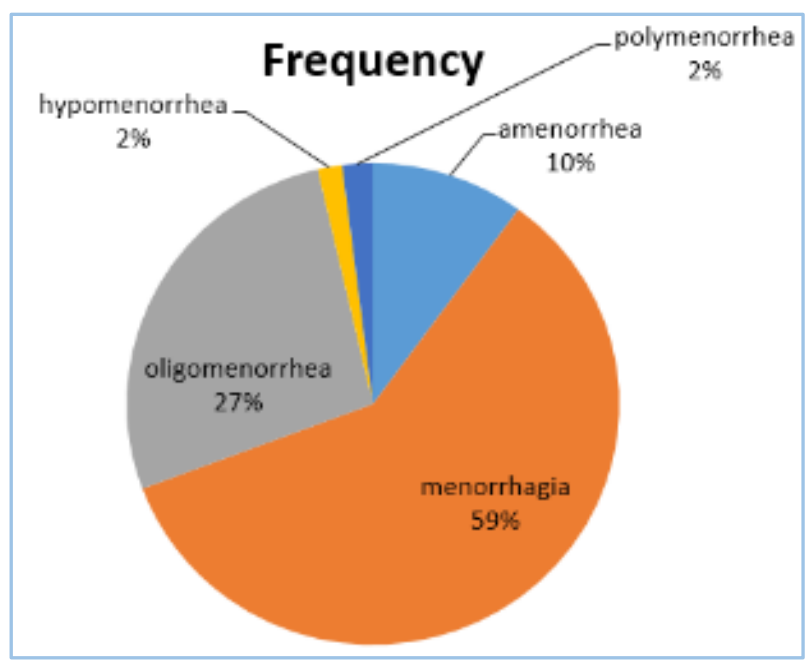

\begin{tabular}{|c|c|c|}
\hline $\begin{array}{c}\text { Clinical Uterine } \\
\text { Size }\end{array}$ & Number & Percentage \\
\hline Normal & 242 & $96.8 \%$ \\
\hline Bulky Uterus & 8 & $3.2 \%$ \\
\hline \multicolumn{2}{|c|}{ Table 5: Gynaecological Examination } \\
\hline
\end{tabular}

\begin{tabular}{|c|c|c|}
\hline $\begin{array}{c}\text { Endometrial } \\
\text { Histology }\end{array}$ & Number & Percentage \\
\hline Secretory & 55 & $22 \%$ \\
\hline Proliferative & 177 & $70.8 \%$ \\
\hline Hyperplasia & 18 & $7.2 \%$ \\
\hline \multicolumn{2}{|c|}{ Table 6: Dilatation and Curettage } \\
\hline
\end{tabular}

\begin{tabular}{|c|c|c|}
\hline T3 & Number & \% \\
\hline$<1.7$ & 39 & $15.6 \%$ \\
\hline $1.7-4.2$ & 193 & $77.2 \%$ \\
\hline$>4.2$ & 18 & $7.2 \%$ \\
\hline \multicolumn{2}{|c|}{ Table 7: T3 Values $(\mathbf{1 . 7 - 4 . 2} \mathbf{~ g ~} / \mathbf{m L})$} \\
\hline
\end{tabular}

\begin{tabular}{|c|c|c|}
\hline T4 & Number & \% \\
\hline$<0.7$ & 39 & $15.6 \%$ \\
\hline $0.7-1.8$ & 193 & $77.2 \%$ \\
\hline$>1.80$ & 18 & $7.2 \%$ \\
\hline \multicolumn{2}{|r|}{ Table 8: T4 Values $(0.7-1.8 \mathbf{n g} / \mathbf{m L})$} \\
\hline
\end{tabular}

\begin{tabular}{|c|c|c|}
\hline TSH & Number & $\%$ \\
\hline$<0.5$ & 18 & $7.2 \%$ \\
\hline $0.5-5$ & 173 & $69.2 \%$ \\
\hline$>5$ & 59 & $23.6 \%$ \\
\hline \multicolumn{3}{|c|}{ Table 9: TSH Values (0.5-5.0 mIU/mL) } \\
\hline
\end{tabular}

\begin{tabular}{|c|c|c|}
\hline $\begin{array}{c}\text { Type of Thyroid } \\
\text { Dysfunction }\end{array}$ & Number & \% \\
\hline Hypothyroidism & 39 & $15.6 \%$ \\
\hline Normal & 173 & $69.2 \%$ \\
\hline Hyperthyroidism & 18 & $7.2 \%$ \\
\hline Subclinical Hypothyroidism & 20 & $88 \%$ \\
\hline \multicolumn{2}{|c|}{ Table 10: Type of Thyroid Dysfunction } \\
\hline
\end{tabular}

\begin{tabular}{|c|c|c|}
\hline $\begin{array}{c}\text { Menstrual } \\
\text { Dysfunction }\end{array}$ & $\begin{array}{c}\text { Subclinical } \\
\text { Hypothyroidis } \\
\text { m }\end{array}$ & Percentage \\
\hline Oligomenorrhoea & 2 & $5 \%$ \\
\hline Menorrhagia & 14 & $70 \%$ \\
\hline Amenorrhea & 4 & $25 \%$ \\
\hline $\begin{array}{c}\text { Hypo and } \\
\text { Polymenorrhea }\end{array}$ & 0 & $0 \%$ \\
\hline \multicolumn{2}{|c|}{ Table 11: Menstrual Dysfunction in } \\
Subclinical Hypothyroidism
\end{tabular}

\section{DISCUSSION}

Abnormal uterine bleeding is a benign yet debilitating disease with strong association with thyroid disorders. This study highlights the association between AUB and thyroid dysfunction.

In our study, the mean age of women with thyroid dysfunction was 36 years. C A Petta et al. 2007 in their crosssectional study carried out in 148 women with menstrual dysfunction found a mean age of 34.6 years. ${ }^{1}$ Vanderpump MP et al. 1995, in their 20 years follow-up of Whickam survey had a mean age of 34 years. ${ }^{2}$ Sampath S et al. 2007, in their study on clinico-biochemical spectrum of hypothyroidism found a mean age of 36.2 years. ${ }^{3}$

In this study, the presence of infertility (5.6\%) and $\mathrm{H} / \mathrm{O}$ abortions $(8.8 \%)$ were associated with significant thyroid abnormalities. This prevalence is not coincided with $29 \%$ prevalence of thyroid dysfunction described by Poppe et al. 2002 in their study on thyroid dysfunction in infertile women. ${ }^{4}$ Because in a previous study the sample population consisted 
of women with infertility, whereas in present study the sample population taken from general gynaec clinic.

In this study, we found an association in the occurrence of menorrhagia (59.2) in hypothyroid women. In a study by Andrew D Weeks 2000, 56\% had menstrual disturbances and the most common complaint was menorrhagia (36\%). ${ }^{5}$ Col $\mathrm{P}$ Singh et al. 2007, in their analysis of menstrual dysfunction among hypothyroid women stated menorrhagia was seen in $32.4 \%$ of hypothyroid women. ${ }^{6}$

The overall prevalence of thyroid dysfunction in the present study was $30.8 \%$. This correlates with other studies; Prentice et al. medical management of menorrhagia stated $36 \%$ of women with thyroid abnormalities had menstrual dysfunction. ${ }^{7}$ In another study by Wilansky et al. 1999 had $22 \%$ prevalence among patients with thyroid disorder. ${ }^{8}$

The prevalence of subclinical hypothyroidism in reproductive age group women with abnormal uterine bleeding was $8 \%$. The prevalence studies have reported incidences between 4-10\% (Mark PG et al. 1995). ${ }^{9}$ Hollowell JG et al. 2002 observed $8.3 \%$ prevalence of subclinical hypothyroidism in their study. ${ }^{10}$ There is a good evidence to support the fact that treatment of patients with subclinical hypothyroidism prevents progression to overt hypothyroidism (Surks MI 2004). ${ }^{11}$ Failed medical therapy of dysfunctional uterine bleeding may be due to underestimate of underlying thyroid disorder.

\section{SUMMARY}

Abnormal uterine bleeding is a benign debilitating diseases with strong association with thyroid disorder. This study highlights the association between AUB and thyroid dysfunction.

- In our study group, the main age of thyroid dysfunction was 36 years.

- In this study, we found an association in the occurrence of menorrhagia (70\%) in subclinical hypothyroid women.

- In the present study, $51 \%$ detected to have a hypothyroidism.

- In this study, the presence of infertility (2.4\%) and history of abortions (5.2\%) were associated with thyroid disorders.

- Prevalence of subclinical hypothyroidism is around 8\%.

The prevalence of preclinical hypothyroidism was $8 \%$. Detection of this group of women is considered a major benefit of testing, because supplementation of thyroxine to these women will revert back their symptoms. Hence, testing for thyroid function is advocated early in the course of disease.

\section{CONCLUSION}

\section{Our Study Highlights the Following}

- There is a significant association between thyroid disorder and abnormal uterine bleeding.

- It brings into focus the increased incidence of hypothyroidism among women with menorrhagia and amenorrhea.

- Prevalence of subclinical hypothyroidism is around 8\%.

- It is suggested that women with early onset menorrhagia and oligomenorrhoea attributable to thyroid dysfunction should be offered thyroid function test to detect them in subclinical stage.

- Early detection by selective screening and specific pharmacotherapy for subclinical thyroid disease early in the course of disease was beneficial.

\section{REFERENCES}

1. Petta CA. Thyroid screening in menstrual abnormalities. $\mathrm{N}$ Eng J Med 2007;76:463-70.

2. Vanderpump MP, Tunbridge WM, French JM, et al. The incidence of thyroid disorders in the community: a twenty five year follow up of whickam survey. Clin Endocrinol (Oxf) 1995;43(1):55-68.

3. Cdr S Sampath, Somani BL, Col MM Arora, et al. Study of clinico biochemical spectrum of hypothyroidism. MJAFI 2007;63(3):233-6.

4. Poppe K, Glinoer D, Van Steirteghem A, et al. Thyroid dysfunction and autoimmunity in infertile women. Thyroid 2002;12(11):997-1001.

5. Andrew D Weeks. Correlating menstrual irregularities with levels of thyroid hormone deficiency. BMJ 2000;320(7235):649.

6. Col P Singh. Pattern of bleeding in hypothyroidism. MJAFI 2007;53:112-23.

7. Prentice A. Medical management of menorrhagia. Am J Obstet Gynaecol 1999;319(7221):1343-5.

8. Wilansky DL, Greisman B. Early hypothyroidism in patients with menorrhagia. Am J Obstet Gynecol 1989;160(3):673-7.

9. Mark PG, Burman KD. Overt and subclinical hypothyroidism in women. O \& G surv 1995;61(8):345-56

10. Hollowell JG, Staehling NW, Flanders WD, et al. Serum T4 and TSH in the united states population (1988-1994): national health and nutrition examination survey (NHANES III). J Clin Endocrinol Metab 2002;87(2):489-99.

11. Gharib H, Tuttle RM, Baskin HJ. Subclinical thyroid dysfunction: a joint statement on the management from the American association of clinical endocrinologists, the American thyroid association, and the endocrine society. J Clin Endocrinol Metab 2005;90(1):586-7. 